\title{
INTRODUCTION TO SYMPOSIUM ON PIERRE-HUGUES VERDIER AND ERIK VOETEN, "PRECEDENT, COMPLIANCE, AND CHANGE IN CUSTOMARY INTERNATIONAL LAW: AN EXPLANATORY THEORY"
}

\author{
Ingrid Wuerth*
}

AJIL Unbound is pleased to announce three commentators who will discuss the article by Pierre-Hugues Verdier and Erik Voeten entitled "Precedent, Compliance, and Change in Customary International Law: An Explanatory Theory." 1 The article argues that rational choice scholars have overlooked key characteristics of customary international law and that those characteristics undermine the enforcement of customary norms through decentralized punishment. Instead, Verdier and Voeten contend, states may comply with customary international law even if their short-term interests are to defect, because states know that their decision to defect generates precedent that undermines the norm as a whole. Our commentators on this article are, first, Professor Tim Meyer, from the University of Georgia, who maintains ${ }^{2}$ that Verdier and Voeten overstate the distinction between custom and treaties. Second, Professor Jens David Ohlin, from Cornell, asks ${ }^{3}$ what happens to custom when states cannot appeal to long-term interests. He argues that compliance in these "one-shot" scenarios can be understood partly by considering the formation of plans by states which may act rationally in carrying through on their obligations without re-evaluating their plans. Finally, Professor Alejandro Lorite Escorihuela, from the University of Quebec at Montreal, argues that the role of precedent is clear from both the doctrine and practice of customary international law, so that it is unclear what rational choice methodology is adding to our understanding of custom, a critique he buttresses in part through an examination of some of the examples discussed in the article.

* Professor of Law at Vanderbilt Law School.

Originally published online 5 Apr. 2015.

${ }^{1}$ Pierre-Hugues Verdier \& Erik Voeten, Precedent, Compliance, and Change in Customary International Law: An Explanatory Theory, 108 AJIL 389 (2014).

2 Timothy Meyer, How Different are Treaties and Modern Customary International Law? A Response to Verdier and Voeten, 108 AJIL UNBOUND 240 (2015).

${ }^{3}$ Jens David Ohlin, Precedent and Custom: A Response to Verdier and Voeten, 108 AJIL Unbound 246 (2015).

ASIL and Ingrid Wuerth (C) 2015 